\title{
Erratum to: Developing a mHealth intervention to promote uptake of HIV testing among African communities in the UK: a qualitative study
}

\author{
C. Evans ${ }^{1 *}$, K. Turner ${ }^{1}$, L. S. Suggs ${ }^{2}$, A. Occa ${ }^{2,3}$, A. Juma ${ }^{4}$ and H. Blake ${ }^{1}$
}

\section{Erratum}

Upon publication, the following error was introduced to the title of this article [1]: The 'UK' was incorrectly changed to 'conditions'.

The correct title should read: 'Developing a mHealth intervention to promote uptake of HIV testing among African communities in the UK: a qualitative study'.

The correct title has been included in this erratum and has also been updated in the original article.

\footnotetext{
Author details

'School of Health Sciences, University of Nottingham, A Floor, South Block Link, Queen's Medical Centre, Nottingham NG7 2HA, UK. ${ }^{2}$ BeCHANGE Research Group, Institute for Public Communication, Faculty of Communication Sciences, Università della Svizzera italiana, Lugano, Switzerland. ${ }^{3}$ School of Communication, University of Miami, Miami, USA.

${ }^{4}$ African Institute for Social Development, Nottingham, UK.
}

Published online: 08 September 2016

\section{Reference}

1. Evans $\mathrm{C}$, et al. Developing a mHealth intervention to promote uptake of HIV testing among African communities in the UK: a qualitative study. BMC Public Health. 2016;16:656. doi:10.1186/s12889-016-3278-4.

\footnotetext{
* Correspondence: catrin.evans@nottingham.ac.uk

${ }^{1}$ School of Health Sciences, University of Nottingham, A Floor, South Block Link, Queen's Medical Centre, Nottingham NG7 2HA, UK

Full list of author information is available at the end of the article

Submit your next manuscript to BioMed Central and we will help you at every step:

- We accept pre-submission inquiries

- Our selector tool helps you to find the most relevant journal

- We provide round the clock customer support

- Convenient online submission

- Thorough peer review

- Inclusion in PubMed and all major indexing services

- Maximum visibility for your research

Submit your manuscript at www.biomedcentral.com/submit 